DOI: https://doi.org/10.31392/NPU-nc.series9.2018.18.07

UDC: 81 '0

Nataliia D. Kishchenko

National Pedagogical Dragomanov University,

Kyiv, Ukraine

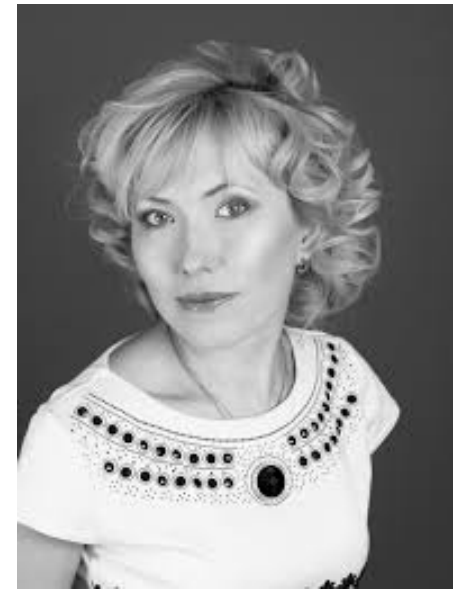

\title{
MODELS OF ARTISTIC-FIGURATIVE METAPHORS OF WISDOM IN ENGLISH FAIRY TALES
}

\section{Bibliographic Description:}

Kishchenko, N. D. (2018). Models of Artistic-Figurative Metaphors of Wisdom in English Fairy Tales. Scientific Journal of National Pedagogical Dragomanov University. Series 9. Current Trends in Language Development, 18. 87-94. DOI: https://doi.org/10.31392/NPU-nc.series9.2018.18.07

Abstract

The article uses a cognitive-semantic approach to the study of metaphor, through which prisms all abstract phenomenon is considered as an image sensory knowledge and perception of the world, existing in the experience of the speaker. An attempt has been made, on the one hand, to differentiate language, artistic and folk-poetic metaphors, on the other hand, to consider them as components of a conceptual metaphor, which includes artistic figurative metaphors of Wisdom. The correlation between the metaphorical concept and the conceptual metaphor, which forms the two main layers: figurative and value, is specified. The spheressources of conceptual art-figurative metaphors of Wisdom in the discourse of English-language fairy tales, revealing schemes of rethinking of the phenomena of the world and the mechanisms of metaphorisation are revealed.

It has been established that metaphorically, wisdom has the size, it can vary, grow and develop, is a certain thing that a person has, has quantitative parameters inherent in animals, inherent in non-existence in general, is love, a receptacle for storing information, is differentiated on the basis of youth and old age, is a description of the environment, some surface, has a voice, is the key to understanding and identifying meaning, and so on. It is proved that in the discourse of the English-speaking fairy tale, Wisdom appears as the actual concept, formed on the basis of conceptual metaphors. Conceptual metaphors that form the concept of wisdom are represented by five major productive metaphorical models with their submodels: WISDOM is a LIGHT; WISDOM is a MIRROR; WISDOM is the FIRE; WISDOM is an OBJECT; WISDOM is HUMAN.

Keywords: artistic-figurative metaphor, metaphorical models, cognitive mechanisms, metaphors of wisdom, English-language fairy tale.

\section{Introduction.}

The nature of the correlation of language as a variety of means of expression and linguistic metaphor as one of the most burdensome means corresponds to the complex and still unresolved problem of communication of folk-colloquial / folklore and artistic speech. In the process of studying this issue, researchers eventually differentiated between such adjoining but not identical concepts, such as linguistic and artistic metaphor. The main 
difference between these entities was explained by the fact that the linguistic metaphor has a semantic equivalent in the language system, in contrast to the artistic metaphor.

However, Popova also highlights a potential metaphor, which functions as a ready lexical unit, but which is not generalized in dictionaries (i. e. in the language system). This metaphor has an analogy with linguistic metaphors, while it is different from those of higher order, which are created on non-standard metaphorical bonds. And the very existence of significant creative potential prevents the introduction of this metaphor into the language system. Such metaphors, as a rule, are popular in folk poetry, in its various products, including fairy tales. In addition, these metaphors can be generated on the basis of artistic images, turning into a colloquial language, and vice versa (Popova 2003: 59).

Most of them acquire the status of conceptual metaphors of a particular culture, which includes the metaphors of Wisdom.

Wisdom has been repeatedly tried to comprehend in philosophy (Batsevich, 2004; Benvenist, 1974; Karasik, 1999), psychology (Fillmore, 1988) in sociology (Stepanov, 2001) repeatedly as a phenomenal ability of man, cultural studies and others like that.

Actually in linguistics from the standpoint of the cognitive-discursive paradigm, WISDOM / WISDOM was viewed as a concept in the spiritual-mentalistic aspect, as well as one of the teleonomic concepts (Sternin, 1974), which is the highest, spiritual and valuable property of the individual. And previous observations of the structure of this metaphorical concept give reason to suppose that it is a universal phenomenon inherent in various linguocultures (Losev, 1978 et al.). At the same time, giving the status of a metaphorical concept to the concept of Wisdom still needs to clarify its cognitive essence, first of all, in terms of determining the relationship with the conceptual metaphor of wisdom, actualized in artistic texts through the prism of folk-poetic creativity. To this end, we will summarize the cognitive nature of the artistic and folk-poetic metaphors in general.

\section{Cognitive-Conceptual Essence of Metaphor.}

As already mentioned above, the modern scientific paradigm of linguistics is characterized by a cognitive-discursive vector, which is observed in the study of metaphor and which has recently been called a conceptual phenomenon.

Currently, there are several cognitive theories of metaphor, which are viewed on the background of other interpretations of the nature of the metaphor of its conceptual basis.

1. According to the theory of Losev, the basis of the metaphor is the deep thought process - the implementation of comparison by analogy, which reflects the set of logicalcognitive operations. The researcher attributes the metaphor to the primary cognitive function, which is inseparable from rational thought and the process of awareness of the phenomena of bout (Losev, 1978: 623).

Formulating the definition of a metaphor, Losev emphasizes, first of all, the cognitive mechanism of analogy as a logical-cognitive operation (Losev, 1978: 623). This cognitive mechanism is universal, based on the psychological process of association, under which Novikov in the cognitive-conceptual plan understands psychological and psychological operation, based on the ability of man to combine the real, true properties of the object with the characteristics of other objects, integrated into the human consciousness (Novikov 1983: 124-137).

But, as it seems to us, the representatives of Gaskell's theory only partly explain the constitutive nature of the process of metaphorisation.

2. The most widespread theory in which the cognitive and at the same time the conceptual essence of the metaphor is developed is the concept of Lacoff and Johnson, whose subject matter was the everyday (naive) metaphor. 
According to Stepanov, "everyday used metaphors are used to structure the surrounding reality and control the intellectual activity of man and his actions. And it is here that the conceptual essence of the metaphor lies, for, as the scientist points out, the everyday conceptual system of the person whose categories she thinks is essentially metaphorical and plays a significant role in designating everyday realities" (Stepanov, 2001: 990).

3. And another view of the cognitive essence of the conceptual metaphor is obviously promising, whose representatives (Sternin, 1974 et al.) Believe that the metaphorical meaning is not elemental, since it is created as a result of a whole complex of knowledge processing, and not only on the basis of analogies and associations. And in this case, it is worth agreeing with Sternin, who, quoting Fillmore, states: "The cognitive metaphor is an instrument and at the same time the result of cognitive processes that forms new psychic categories, new conceptual systems, generates new knowledge, etc." (Sternin, 1974: 447).

After reviewing the views of the representatives of the three theories of cognitive metaphor, we assume that the metaphor is a conceptual entity that reflects the complex processes of knowledge, fixation and interpretation of the phenomena of the surrounding world and which most thoroughly reveals the theory of conceptual integration of Fauconnier and Turner.

\section{Cognitive Mechanisms of Creation of Artistic-Figurative Fabulous Metaphors of Wisdom.}

The cognitive approach to the study of metaphor contributes to the fact that any abstract phenomenon can be explained as the image of sensory perception of the world that exists in the speaker's experience. This process is accompanied by an axiological assessment. At the same time, the description of the abstract phenomenon can be carried out through a more specific situation.

Thus, the artistic potential of the metaphor lies in their ability to transform into new images that prove the originality of reflection (comprehension) of the world by native speakers of different languages. Thus, in the process of artistic knowledge of the world, conceptual metaphors undergo changes, because they are based on the cognitive mechanisms of creative rethinking.

Creation of a vivid image is based mainly on contrast - the cognitive mechanism that underlies the creation of figurative metaphors. Considering, on the one hand, the figurative and valuable layer of the concept, which is formed mainly on the basis of the conceptual metaphors, and on the other hand, the cognitive mechanisms on which they are based, assume that such a methodological approach will enable to reveal not only the schemes of metaphorical simulation of Wisdom in English-language fairy tales, but also to reveal a valuable attitude towards this phenomenon in general.

In English-language tales, their authors created a kind of syncretic - an artistic and folk-poetic image, which we propose to call a fabulous metaphorical image. This image is created using such figurative metaphors that do not belong to any classical artistic image. The conceptual metaphor of Wisdom is based on giving the heroes of fairy tales unspecified features and sometimes absurd. Let's consider the most typical patterns and models of figurative metaphors of wisdom in English-language fairy tales:

1. The first metaphorical model WISDOM is a LIGHT:

Wisdom - the lamp may go away. Example: Her mind seemed to darken when she tried to think of it. There came upon my dark and troubled mind a calm, as when the tumult of the City suddenly ceases. With the darkness came a darkness into Tenar's mind, so that she understood less and less of what was said (Nesbit, 1993: 224 p.). 
Wisdom has a quality of transparency. Example: It was, indeed, a difficult matter to obtain a legal commitment to the hospital, so powerful and lucid did the youth's mind seem (Popova, 2003: 59 p.).

I grant, at least, that there are two distinct conditions of my mental existence -the condition of a lucid reason, not to be disputed, and belonging to the memory of events forming the first epoch of my life - and a condition of shadow and doubt, appertaining to the present, and to the recollection of what constitutes the second great era of my being.

Wisdom may shine. Example.: Her none too brilliant mind was not of much service in this crisis (Oxford Dictionary, 2009: 1907).

The moment this permission was accorded, the countenance of Uncas changed from its grave composure to a gleam of intelligence and joy (The Columbia Encyclopedia, 2015 URL: http://www.encyclopedia.com/topic/Rotterdam.aspx.).

He had even thought of retreating beyond a curvature in the natural wall, which might still conceal him and his companions, when by the sudden gleam of intelligence that shot across the features of the savage, he saw it was too late, and that they were betrayed (Shisler, 1997 URL http://reocities.com/SoHo/Studios/ 9783/phond1.html.).

Those large, clear gray eyes were full of intelligence (Shisler, 1997 URL http://reocities.com/SoHo/Studios/ 9783/phond1.html.).

Wisdom may have color. Example: It was, indeed, a difficult matter to obtain a legal commitment to the hospital, so powerful and lucid did the youth's mind seem.

I grant, at least, that there are two distinct conditions of my mental existence - the condition of a lucid reason, not to be disputed, and belonging to the memory of events forming the first epoch of my life - and a condition of shadow and doubt, appertaining to the present, and to the recollection of what constitutes the second great era of my being (Shisler, 1997 URL http://reocities.com/SoHo/Studios/ 9783/phond1.html.).

2. The second metaphorical model WISDOM is a MIRROR: Wisdom has the properties of a mirror. Example: This is only the Mirror of Wisdom.

But suffer me to enter into thee again, and be thy servant, and thou shalt be wiser than all the wise men, and the Wisdom shall be thine. Suffer me to enter into thee, and none will be as wise as thou.

3. The third metaphorical model WISDOM is the FIRE:

Wisdom - fire can sparkle. Example: He hoped at last to get what he had never received before - a rekindled spark of reason and perhaps a normal, living creature.

Wisdom has the qualities of brightness and pallor. Example: He hoped at last to obtain what he had never obtained before - a rekindled spark of reason and perhaps a normal, living creature;

Wisdom may burn. Example: He hoped at last to obtain what he had never obtained before - a rekindled spark of reason and perhaps a normal, living creature.

Then I sank prone to the stone floor, my mind aflame with prodigious reflections which not even a death - like exhaustion could banish (MacMillan, 2012: 1748).

Would to Heaven we had never approached them at all, but had run back at top speed out of that blasphemous tunnel with the greasily smooth floors and the degenerate murals aping and mocking the things they had superseded - run back, before we had seen what we did see, and before our minds were burned with something which will never let us breathe easily again! (Oxford Dictionary, 2009: 1907).

4. The forth metaphorical model WISDOM is an OBJECT:

Wisdom may have shades. Example: It was perhaps an effect of such surroundings that my mind early acquired a shade of melancholy. 
Wisdom has a category of beauty. Example: The beauty and resourcefulness of his mind, which, after hours of intimate contact with her, he was pleased to reveal.

'But then I should not have had my wonderful brains!

Wisdom has a sign of flexibility. Example: And when his small mind bent entirely upon that, Odeen would give in, and then Dua would have to.

Wisdom has a quality of acuity. Example: His mind is finally keen enough to remember what has happened in all those temporary unions during melting (Nesbit, 1993: 224).

She was populous with deep thinkers and subtle intellects (Nesbit, 1993: 190).

Still, so little was he practiced in the arts of deception, that his expressive countenance was, of itself, understood by the quick - witted Judith, whose intelligence had been sharpened by the risks and habits of her life (Nesbit, $1993: 190$ p.).

The Scarecrow decided to think, and he thought so hard that the pins and needles began to stick out of his brains.

Wisdom has elasticity. Example: His mind and will displayed less resilience and initiative (Shisler, 1997 URL: http://reocities.com/SoHo/Studios/ 9783/phond1.html.).

Wisdom has the properties of the cold. Example: Always an ice-cold intellectual machine; slight, blond, blue - eyed, and spectacled (Nesbit, 1993: 224).

He was not without sensibilities of the highest order, only they were governed and controlled in him by that cold iron thing, his reason, which never forsook him.

Wisdom has the property of metal hardness. Example: He was not without sensibilities of the highest order, only they were governed and controlled in him by that cold iron thing, his reason, which never forsook him (Nesbit, 1993: 224).

To give birth to an idea - to discover a great thought - an intellectual nugget, right under the dust of a field that many a brain - plow had gone over before (Nesbit, 1993: 224).

Wisdom May Vibrate. Example: $O$ holy Father! pardon in me the oscillation of a mind (Kipling, 1994: 224).

Wisdom is in the Middle. Example: Sound mind in a sound body.

Wisdom may resize. Example: His head was quite bulged out at the top with brains.

Wisdom has a category of beauty. Example: The beauty and resourcefulness of his mind, which, after hours of intimate contact with her, he was pleased to reveal (Wilde, 1994: 207).

Wisdom - It can be tricky and rewarding. Example: His own shrewd, political mind was working (Wilde, 1994: 207).

He was not more than thirty - seven years of age - a big, flabby sort of person with a crafty mind (Leibin, 2010: 1219).

Wisdom some way. Example.: Pis great competitor, if not his rival, was a brave distinguished in war, notorious for ferocity, and remarkable, in the way of intellect (Leibin, 2010: 1219).

Wisdom is the Way. Example: I do believe that I blushed with shame when this idea crossed my mind (Leibin, 2010: 1219).

Wisdom can fall victim. Example: On such a voyage, with its eternal monotonies, people's intellects deteriorate (Literary Encyclopedic Dictionary, 1987: 751).

5. The fifth metaphorical model WISDOM IS HUMAN:

Wisdom can wander. Example: Has it become to thee a labyrinth never ending, Where thy lost reason strays? (The Dictionary of English Phonaesthemes, 1997 URL http://www.geocities.com.).

Wisdom may be born. Example: The birth of human mind - that is the basis of the universe growth, and not that rubbish you have just uttered (The Dictionary of English Phonaesthemes, 1997 URL: http://www.geocities.com.). 
Wisdom is executioner. Example: Her mind had all her feelings executed (The Oxford Dictionary of English Etymology, 1994: 1042).

Does this have anything to do with intellect, that executioner of yours? (Baum, 1993: $145)$.

Wisdom - Sea or Ocean. Example: The changing color of the waves that break upon the idle sea-shore of the mind! (Carroll, 1994: 160).

Wisdom may be mistaken. Example: Were half the power, that fills the world with terror, were half the wealth, bestowed on camps and courts, given to redeem the human mind from error (Carroll, 2008: 144).

Wisdom has the signs of the ship. Example: My mind, with loosely - hanging sails, lies waiting the auspicious gales (Kipling, 1994: 224). 224).

Wisdom - Servant. Example: And his reason served him damn well (Kipling, 1994:

Wisdom is the mountain. Example: The vision shook the whole mountain of his reason (Kipling, 1994: 224).

Wisdom - It can boast. Example: So long as the boastful human mind consents in such mills as this to grind (Kipling, 2007: 400).

Wisdom may not act. Example: Ye minds that loiter in these cloister gardens, or wander far above the city walls... (Milne, 1994: 284).

Wisdom has a voice, can speak. Example: Your reason told you that I was much more likely to be trapped by you than by him (Milne, 1994: 320).

And it was so easy for the resourceful mind of Frank Cowperwood, wealthy as he was, to suggest ways and means (Wilde, 1994: 207).

Perhaps he has seen enough to change his mind, and make him hear reason (Nesbit, 1993: 224).

Wisdom can sing. Example: "Not only the voice sings," she said. "The mind sings. The prettiest voice in the world's no good if the mind doesn't know the songs." mind.

Wisdom has a category of silence. Example: He yelled and yelled in the silence of his

Wisdom is inherent in animals. Example: 'There is no one in the Jungle so wise and good and clever and strong and gentle as the Bandar-log.'

The river - turtles, had long ago been killed by Bagheera, cleverest of hunters, and the fish had buried themselves deep in the dry mud.

'But are the beasts as wise as the men?' said the chief.

Petersen Sahib came in on his clever she - elephant Pudmini (Fillmore, 1988: 52-92).

There was nothing in the way of fighting that Kala Nag, the old wise Black Snake, did not know, for he has stood up more than once in his time to the charge of the up more than once in his time to the charge of the wounder tiger...

'It's Novastoshnah over again, but ten times better,' said Kotick. 'Sea Cow must be wiser than I thought.

He would go ten miles to the seal - holes, and when he was on the hunting-grounds he would twitch a trace loose from the pitu, and free the big black leader, who was the $c$ leverest dog in the team.

'It's Owl who knows something about something.'

But the Nightingale understood the secret of the Student's sorrow, and she sat silent in tne oak - tree, and thought about the mystery of Love (Wilde, 1994: 207).

\section{Conclusions.}

Exploring the conceptual artistic-figurative metaphor of Wisdom in English-language fairy tales, the spheres-sources of its origin were discovered that reveal the schemes of its 
rethinking. So, metaphorically, Wisdom has a category of size, it may change, it can grow and develop, it is a certain thing that a person possesses, has quantitative parameters inherent in animals, inherent in non-existence in general, is love, a receptacle for storing information, is differentiated on the basis of youth and old age, is a description of the environment, some surface, has a voice, is the key to understanding and identifying meaning, and so on.

In the English-language discourse of tales, Wisdom appears as a conceptual essence: as its own concept, formed on the basis of conceptual metaphors. The main structural components of the concept of wisdom are figurative and valuable. Conceptual metaphors that form the concept of wisdom are represented by five major productive models with their submodels. The first metaphorical model WISDOM is a LIGHT: Wisdom - the lamp may go away; Wisdom has a quality of transparency; Wisdom may shine; Wisdom may have colour; the second metaphorical model WISDOM is a MIRROR: Wisdom has the properties of a mirror; the third metaphorical model WISDOM is the FIRE: Wisdom - fire can sparkle; Wisdom has the qualities of brightness and bliss Wisdom can burn; the fourth metaphorical WISDOM model is an OBJECT: Wisdom may have shades; Wisdom has a category of beauty; Wisdom has a sign of flexibility; Wisdom has a quality of acuity; Wisdom has elasticity; Wisdom has the properties of the cold; Wisdom has the property of metal hardness; Wisdom May Vibrate; Wisdom is in the Middle; Wisdom may resize; Wisdom has a category of beauty; Wisdom - It can be tricky and rewarding; Wisdom some way; Wisdom is the Way; Wisdom can fall victim; the fifth metaphorical model WISDOM is HUMAN; Wisdom can wander; Wisdom may be born; Wisdom is a killer; Wisdom - Sea or Ocean; Wisdom may be mistaken; Wisdom has the signs of the ship; Wisdom - Servant; Wisdom is the mountain; Wisdom - It can boast; Wisdom may not act; Wisdom has a voice, can speak; Wisdom can sing; Wisdom has a category of silence; Wisdom is inherent in animals.

\section{References}

Batsevich, F. S. (2004). Osnovi komunikativnoi lingvistiki [Foundations of communicative linguistics]. K. : Academy.

Benvenist, E. (1974). Obshchaya lingvistika [General linguistics]. M. : Progress.

Fillmore, C. (1988). Frames and semantics of understanding. New in foreign linguistics. Issue. 23: Cognitive aspects of language. 52-92. MIT Press.

Jackendoff, R. (1992). Languages of the mind: Essays on Mental Representation. Cambridge, Mass : The

Karasik, V. I. (1999). Relogioznyi diskurs [Religious discourse]. Language personality: problems of cultural linguistics and functional semantics. 3-18.

Kishchenko, N. D. (2009). Concept of culture as a structure of representation of knowledge about the world. Modern studies in foreign philology, 7. 211-216.

Leibin, V. M. (2010). Dictionary of reference for psychoanalysis. M. : AST.

Losev, A. F. (1978). Estetika Renesansa [Aesthetics of the Renaissance]. M. : Thought.

Novikov, L. A. (1983). Metafora, yeye struktura, semantika i svyaz s tekstom [Metaphor, its structure, semantics and communication with the text]. Linguistic semantics and logic. 124-137.

Popova Z. D., Sternin I. A. (2003). Yazyk i natsionalnaya kartina mira [Language and the national picture of the world]. Voronezh : Sources.

Stepanov, Yu. S. (1998). Yazyk i metod. K sovremennoy filosofii yazyka [Language and method. To modern philosophy of language]. M. : Languages of Russian Culture.

Stepanov, Yu. S. (2001). Konstanty: Slovar russkoy kultury [Constants: Dictionary of Russian Culture]. 2-e izd., kor. i dop. M. : Academic Project.

Sternin, I. A. (1985). Leksicheskoye znacheniye slova v rechi [The Lexical meaning of a word in speech]. Voronezh : Voronezh Publishing House. Un-ta. 


\section{List of Lexicographic Sources}

Literary Encyclopedic Dictionary. ed. V. M. Kozhevnikov, P. A. Nikolaev. M.: Soviet Encyclopedia, 1987. Macmillan English Dictionary for Advanced Learners. M. Rundell. London / New York : MacMillan /A. \& C. Black, 2012.

Oxford Dictionary for Advanced Learners. Oxford: Oxford University Press, 2009.

Shisler, B. K. (1997). Dictionary of English Phonesthemes. Retrieved from http://reocities.com/SoHo /Studios/ 9783/phond1.html.

The Columbia Encyclopedia. 2015. Retrieved from http://www.encyclopedia.com/topic/Rotterdam.aspx. Press, 1994

The Oxford Dictionary of English Etymology. ed. C. T. Onions. Oxford; New York : Oxford University

\section{List of Illustrative Material}

Baum, L. F. (1993). The Wizard of Oz. London : Wordsworth Classics.

Carroll, L. (1994). Alice's Adventures in Wonderland. London : Pinguin Books.

Carroll, L. (2008). Through the Looking - Glass and What Alice Found There. M. : Airis-Press.

Kipling, R. (1994). Puck of Pook's Hill. London : Wordsworth Classics.

Kipling, R. (2007). The Jungle Book and The Second Jungle Book. London : Wordsworth Classics.

Milne, A. A. (1994). The Princess Who Couldn't Laugh. London : Pinguin Books.

Milne, A. A. (1994). Winnie the Pooh and His Friends. London : Pinguin Books.

Nesbit, E. (1993). Five Children and It. London : Wordsworth Classics.

Nesbit, E. (1993). The Phoenix and the Carpet. London : Wordsworth Classics.

Wilde, O. (1994). The Happy Prince and other Stories. London : Pinguin Books.

\section{Бібліографічний опис:}

Кіщенко, Н.Д. (2018). Моделі художньо-образних метафор Мудрості в англомовних казках. Науковий часопис Національного педагогічного університету імені М. П. Арагоманова. Серія 9 Сучасні тенденції розвитку мов, 18. С. 00-00. 87-94. DOI: https://doi.org/10.31392/NPU-nc.series9.2018.18.07

\section{Анотація}

У статті застосовано когнітивно-семантичний підхід до вивчення метафори, крізь призму якого будь-яке абстрактне явище розглядається як образ чуттєвого пізнання й сприйняття світу, щзо існує в досвіді мовия. Зроблено спробу, з одного боку, диференціювати мовні, художні й народнопоетичні метафори, а з іншого, розглянути їх як складники концептуальної метафори, до яких належать і художньо-образні метафори Мудрості. Уточнено співвідношення між метафоричним концептом і концептуальною метафорою, яка утворює основні два його шари: образний $і$ иіннісний. Виявлено сфери-джерела концептуальних художньо-образних метафор Мудрості в дискурсі англомовних казок, які розкривають схеми переосмислення явищ навколишнього світу та механізми метафоризаиії.

Установлено, щуо метафорично Мудрість має розмір, може змінюватися, рости й розвиватися, $\epsilon$ певною річчю, якою володіє людина, має кількісні параметри, властиві тваринам, притаманна неістотам взагалі, є любов'ю, вмістилищем для зберігання інформації, диференціюється за ознаками молодості та старості, є описом навколишнього середовища, деякою поверхнею, має голос, є ключем до розуміння й виявлення смислу тощуо.

Доведено, щзо в дискурсі англомовної казки Мудрість постає як власне концепт, утворений на основі концептуальних метафор. Концеетуальні метафори, які утворюють концепт Мудрість, представлені п'ятьма основними продуктивними метафоричними моделями з їх субмоделями: WISDOM is a LIGHT; WISDOM is a MIRROR; WISDOM is the FIRE; WISDOM is an OBJECT; WISDOM is HUMAN.

Ключові слова: художньо-образна метафора, метафоричні моделі, когнітивні механізми, метафори Мудрості, англомовна казка. 